Scissors, paste, and the female editor: The making of the Dutch women's magazine De Gracieuse (1862-64)

Marianne Van Remoortel

Department of Literary Studies, Ghent University, Ghent, Belgium

Marianne.VanRemoortel@UGent.be 


\title{
Scissors, paste, and the female editor: The making of the Dutch women's magazine De Gracieuse (1862-64)
}

\begin{abstract}
This article examines the popular long-running Dutch women's magazine $D e$ Gracieuse (1862-1936). More particularly, it focuses on its foundation and first two years of publication (1862-64), before De Gracieuse became an official edition of - and almost identical to - the internationally successful German fashion and needlework magazine Der Bazar (1855-1936). Combining archival research of the publisher's correspondence with digital searching of nineteenthcentury periodical databases not only reveals the wide variety of foreign periodicals from which the early Gracieuse sourced material. It also reveals the formative input of three women working behind the scenes as editors. As this article will show, these women turned the common nineteenth-century practice of 'scissors-and-paste' journalism into a creative tool for shaping a new type of women's magazine for the Dutch market.
\end{abstract}

Keywords: De Gracieuse, Der Bazar, fashion magazine, female editorship, women's magazine, scissors-and-paste journalism

This work was supported by the H2020 European Research Council under the ERC Starting Grant agreement no. 639668.

Marianne Van Remoortel is Associate Professor of English Literature at Ghent University, Belgium. She is the author of Lives of the Sonnet, 1787-1895: Genre, Gender and Criticism (Ashgate, 2011) and Women, Work and the Victorian Periodical: Living by the Press (Palgrave, 2015), editor-in-chief of the Journal of European Periodical Studies, and director of the ERC Starting Grant project "Agents of Change: Women Editors and Socio-Cultural Transformation in Europe, 1710-1920." Correspondence to: Marianne Van Remoortel, Department of Literary Studies, Ghent University, Blandijnberg 2, 9000 Ghent, Belgium. Email:

Marianne.VanRemoortel@UGent.be

De Gracieuse (1862-1936) was a magazine for women published by A. W. Sijthoff in Leiden, the Netherlands. For most of its long lifespan, it was the official Dutch edition of Der Bazar (1855-1936), a successful German periodical with a strong focus on fashion whose name survives today in its American edition, Harper's Bazaar (1867-). 
The content of De Gracieuse was almost completely identical to Der Bazar's. The illustrations were the same; the texts were carefully translated from the German. This affiliation was part of a significant trend towards internationalisation in fashion publishing in the second half of the nineteenth century. The market was dominated by a handful of publishers who capitalised on the lowering production and transportation costs to expand their reach beyond national borders. Press magnates such as Louis Schäfer, the Berlin publisher of Der Bazar, Franz Lipperheide of Die Modenwelt (Berlin, 1865-1942), and Adolphe Goubaud of Le Moniteur de la mode (Paris, 18431913) negotiated contracts with colleagues in Europe and across the Atlantic to establish foreign editions of their magazines or annex existing titles. ${ }^{1}$ The nineteenthcentury fashion press as a consequence became increasingly streamlined into brands. Growing audiences across the globe were fed the same hand-coloured fashion plates, the same dress patterns, the same images of the same bodices, shawls, and mantles, presented under similarly styled mastheads and with page layouts closely modelled on those of the parent publications.

At a time when copyright law offered little protection to fashion publishers, international branding was an effective strategy to curb the unauthorized and often unacknowledged copying of material from one periodical to another. De Gracieuse was a case in point. During the first two years of its existence, before the official affiliation with Der Bazar, it was a general women's magazine published independently by Sijthoff featuring fiction, poetry, articles, and book reviews alongside needlework patterns and fashion advice. Little of the content was original, and Der Bazar at this point was one of several foreign magazines from which it sourced material.

In the nineteenth century, this recycling material from other publications was more generally known, and often dismissed, as 'scissors-and-paste' journalism. ${ }^{2}$ As Stephan Pigeon observes, historians of the press, too, have long 'discounted it as a straightforward task of reading, cutting, and pasting an old text to make it "new" again' ${ }^{3}$ More recently, however, scissors-and-paste journalism has garnered increasing interest as a crucial way in which news and other types of content travelled within national boundaries as well as internationally, across the Atlantic or in a colonial context. ${ }^{4}$ Scholars such as Pigeon, M. H. Beals, and Will Slauter, moreover, have pointed out that scissors-and-paste journalism covered a more complex set of reuse practices than the term suggests. It was first and foremost an editorial strategy, whereby editors acted as 'gatekeepers' scanning other publications on a regular basis, only 
allowing through what they deemed suitable for republication. ${ }^{5}$ As Pigeon demonstrates, this could also be a 'three-step process of cut, revise, and paste' as text items were transferred from one cultural context to another. ${ }^{6}$ His case study deals with the British women's magazine the Ladies' Treasury (1857-95), whose editor Eliza Warren Francis selected, modified, and repackaged material from American periodicals to suit the magazine's British middle-class readership.

My article builds on this earlier scholarship by examining text and image reuse in De Gracieuse as a creative editorial 'gatekeeping' practice across language boundaries. ${ }^{7}$ It focuses on the first two years of the magazine's existence, from October 1862 until December 1864, as well as on the months leading up to the first issue. This brief period in the history of the magazine deserves closer attention because the early Gracieuse was by no means a simple 'scissors-and-paste' job. It was a rich collage of textual and visual materials sourced from different types of periodicals in French, German, and English, and integrated into the magazine in a variety of ways. To trace these patterns of reuse, I have researched across several large-scale digitisation projects, including Memory of the Netherlands, Gallica, Gale Cengage 19th Century UK Periodicals, Google Books, and the University and State Library Düsseldorf Digital Collections. My main method for identifying sources of text reuse across languages was performing full-text searches for names, keywords and phrases in various possible translations until a match was found. To map the illustration reuse, I opted for manual visual comparison. While several researchers are exploring the possibilities of computer vision methods for studying image use and reuse in historical corpora, manual visual comparison is still the most viable way to study small corpora, particularly those with a

high number of highly similar images like fashion illustrations. ${ }^{8}$ In addition, I conducted archival research in the Digital Collections of Leiden University Library, which hold scans of the publisher's archive. The Sijthoff Archive presents an opportunity rarely afforded to scholars of the press: to complement the study of the published object with a look behind the scenes at the magazine-in-the-making. Crucially, letters in the Sijthoff Archive document the creative input of three female editors, shedding light on their pivotal roles as 'scissors-and-paste' gatekeepers in shaping a new type of women's periodical with an international outlook for the Dutch magazine market.

\section{Planning De Gracieuse}


Sijthoff's correspondence reveals that his plan to launch a periodical for women started to materialise in the spring of 1862 , when he offered the editorship to two sisters, Susanna Maria (1818-82) and Johanna Weeveringh (1820-87). They were unmarried, in their early forties, and well equipped for the job ahead. Susanna Maria had previously worked as an embroiderer, and from 1853 onwards, they ran their own needlework business in Haarlem, selling a wide variety of needlework supplies, giving instructions to customers, and taking orders for partially or fully completed articles from those who lacked the time to do the work themselves. ${ }^{9}$ In addition, they had over a decade of editorial experience on the successful Dutch women's magazine the Aglaja (1848-64), published by Sijthoff's colleagues A. C. Kruseman in Haarlem (1848-57) and Joh. Noman \& Zn. in Zaltbommel (1858-64). ${ }^{10}$ Selling cheaply at 25 cents for a single issue and 3 guilders for an annual subscription, the Aglaja purchased its patterns directly from the renowned Maison Sajou in Paris and had them printed locally by the Dutch lithography firm of Emrik \& Binger of Haarlem. The hand-coloured fashion plates were supplied by Adolphe Goubaud, with whom Kruseman also negotiated a French edition of the Aglaja, entitled Cendrillon (1850-72). The French translations were provided by Kruseman's wife Anna Maria, née Goteling Vinnis (1819-92). ${ }^{11}$ Although this did not transpire on the pages of the periodical, editing the Aglaja was evidently a joint effort shaped by professional as well as friendly and family relationships. This was valuable experience for the Weeveringh sisters, for De Gracieuse would adopt a similar model.

Sijthoff did not approach the Weeveringh sisters directly. He contacted them through their brother, his friend the publisher J. J. Weeveringh, who was also Kruseman's accountant. On April 2, 1862, Weeveringh wrote to Sijthoff that his sisters had accepted the position on the condition that they would be in charge of the fashion and needlework pages only. Unlike the Aglaja, De Gracieuse was to have a literature section as well, making it, as Lotte Jensen notes, more similar to an older predecessor, Penélopé (1821-35), headed by the Dutch author, editor, and pedagogue Anna Barbara van Meerten-Schilperoort (1778-1853). ${ }^{12}$ Unlike Penélopé, however, De Gracieuse explicitly associated itself with the international fashion press. ${ }^{13}$ This is already evident from the Weeveringh sisters' earliest plans for the new magazine as laid out in their brother's letter to Sijthoff. Estimating they would need approximately twelve pages a month, they proposed four sections: needlework, (children's) fashions, miscellaneous matter, and correspondence. In addition, they asked Sijthoff for subscriptions to nine magazines, reassuring him that some could presumably be cancelled soon for not 
meeting their expectations. Three magazines on the list are Dutch: the Aglaja, Maandschrift voor dames (1856-62), and the fashion magazine De Bazar (18571900?), published by the Brothers Belinfante in The Hague and confusingly unrelated to the German Bazar published by Schäfer. The others are French, English, and German titles: Cendrillon, the French edition of the Aglaja; Journal des dames et demoiselles (1841-1902), the Belgian edition of Le Moniteur de la mode; the British women's magazines the Lady's Newspaper (1847-63) and the Ladies' Companion (1849-70); Der Bazar and its French edition La Mode illustrée (1860-1937), which they requested 'with album', a collection of fifty-two hand-coloured fashion plates issued as weekly supplements to the magazine. ${ }^{14}$

The list contains a number of annotations suggesting that someone set to work to retrieve copies (see Figure 1). With the exception of Cendrillon, all titles are crossed out, and brief notes specifying particular editions or months of publication were added to each title. 'Le Moniteur dela [sic] mode' and another title (illegible to me) were pencilled in the left margin and then crossed out as well. Did Sijthoff go over the list and jot down his own ideas or suggestions made to him in person? Or was this the hidden hand of an assistant or of Sijthoff's wife, about whom his biographer R. van der Meulen says very little? In any case, these annotations provide tangible evidence not only of the Weeveringh sisters' requests for potential models and scissors-and-paste materials being processed, but also of the collaborative thinking that went into the creation of the magazine.

Weeveringh's letter also relayed his sisters' detailed instructions as to the different types of illustrations De Gracieuse should contain and by whom these should ideally be produced. For the fashion plates they recommended Goubaud, 'because he provides the prettiest and certainly at the lowest cost'. ${ }^{15}$ Goubaud could also occasionally supply clichés - metal casts of the original wood engravings from which the illustrations could be printed locally — although his engravings for Cendrillon were no match for Emrik's 'pretty' illustrations in the Aglaja. By contrast, the sisters were adamant that the 'yellow plates'-large pattern sheets - should not (their emphasis) come from Goubaud but be purchased locally, preferably from Emrik \& Binger, 'just like Kruseman did' for the Aglaja. As for the crochet patterns, they advised Sijthoff to get the samples that Sajou supplied to the shops, as these were presented 'in an infinitely more beautiful way' than the ones that Sajou contributed to Cendrillon. ${ }^{16}$ With regard to canvas work patterns, no French firm in their opinion, not even Sajou, could 
compete with the German manufacturers. Among these Th. Wilh. Meister of Berlin stood out as 'undoubtedly the best (but perhaps also the most expensive)'. Meister would also be a good practical choice: since the Weeveringh sisters already owned most of his patterns, 'they could pass on the suitable numbers while also keeping track of his latest designs'. ${ }^{17}$ To complete his duty as 'intermediary', Weeveringh informed Sijthoff that his sisters asked for a salary of twenty guilders per issue, to be raised to twenty-five in due course, and signed off with a few legal and financial stipulations: 'The Library of the Periodical remains the property of the publisher-not the Editors. The costs of the models etc. are borne by the publisher-not the editors. These costs are estimated at around $f 100$ to $f 125$ a year. ${ }^{18}$

While the editorship of the fashion and needlework pages was settled swiftly, Sijthoff struggled to find someone to head the literature section. Following his sisters' refusal, Weeveringh offered the position to Fréderique Jeanne van Asperen van der Velde-van Heel (1829-1916), wife of Cornelis van Asperen van der Velde, with whom he ran a bookselling business in Haarlem. ${ }^{19}$ On July 15,1862 , he wrote to Sijthoff that 'completely against my expectation' she had declined as well. ${ }^{20}$ Van Asperen van der Velde-van Heel, however, had good reason to be reluctant about taking on nondomestic work. As the Haarlem birth records show, she was already a mother to four small children and pregnant with her fifth child. ${ }^{21}$ Sensing that he was running out of options, Weeveringh added: 'Now I really cannot think of anyone else but Mrs Van Westrheene, however spitefully she always keeps writing to me. ${ }^{22}$ Jacoba van Westrheene-van Heijningen (1821-1900) was well connected to the literary world as an author and prolific translator of English fiction, including Anthony Trollope and George Eliot. She had a column in the monthly review De Tijdspiegel (1844-1921) and had recently published Merkwaardige vrouwen (1860), a collection of sketches of remarkable women for young girls. Her husband was the art critic Tobias van Westrheene, editor of Sijthoff's art journal Kunstkronijk (1840-1910), author of a number of children's books published by Sijthoff, and former editor of the Dutch magazine for young women, Flora (1848-56). Despite these credentials, Weeveringh dreaded the prospect of having to ask her, 'for I am scared of Mrs v. W.!' His reservations were so strong that she was second choice to Van Asperen van der Veldevan Heel, who appears to have been much less experienced and spending a significant amount of her time on household duties. Although the reason for his misgivings remains 
unclear, the question of who was going to edit the literary section of the new magazine was evidently as much an emotional as a professional one.

As a final, almost desperate resort, Weeveringh suggested Mrs Busken Huet. Anne Busken Huet-van der Tholl (1827-98) was an author and translator of English and French fiction. Her Dutch translation of George Eliot's 1859 novel Adam Bede was published by Kruseman in 1860; Geschiedenis van een hapje brood (1862), a translation of the children's book Histoire d'une bouchée de pain (1860) by Jean Macé, had just come out with the same publisher. Despite these qualifications, there was one complication that needed to be addressed first: she would have to remain completely anonymous, not only to the readers of the magazine but also to those involved on the production side. If this was a reputation issue, the question remains: whose reputation needed protection? It is likely that Busken Huet-van der Tholl did not want to be publicly known as the editor of a women's magazine. Her earlier periodical work were stories published anonymously or under the pseudonym 'Ina' in respectable literary and religious almanacs such as Aurora (1840-77) and the Christelijke volks-almanak (1844-80). Perhaps she was also concerned about the reputation of her husband, Conrad Busken Huet, who had resigned from his pastor position in January and was now pursuing a career in journalism. Weeveringh himself may also have been worried about the reputation of De Gracieuse, for Busken Huet was a polemical figure both as a theologian and a literary critic. Whatever the reason, it was important enough for him to engage in some careful plotting in order to keep her identity a secret. In one possible scenario he proposed to Sijthoff, his sisters would serve as official editors of the entire publication, including the literary section:

Is there really no way of having Mrs Busken Huet and disguising her in such a way that she remains completely unrecognisable? No editor is named; my sisters send the copy for the fashions. Cannot they receive and send the proofs etc. of Mrs B. H., back and forth? Indeed, cannot my sisters take full charge of the editorship and assume responsibility of the literature, so that Mrs B. H. stays in the background altogether? My sisters would then only be the intermediaries between you and the actual editor. $^{23}$

Realising the arrangement could raise suspicion, Weeveringh immediately offered an alternative: 'Or instead of my sisters, of whom one (?) could think they know nothing besides needlework, do you want my wife, about whom no one knows anything?'24 
Weeveringh's wife was a young woman of British descent by the name of Sarah Thorp (1836-1906) whom he had married in Manchester two years earlier and who was clearly considered enough of an outsider to provide a mask for Busken Huet-van der Tholl. ${ }^{25}$ The post scriptum to Weeveringh's letter shows that she was to some degree already involved behind the scenes: 'My wife reminds me that the title underneath the fashion plates is Fashions Expressly prepared and designed for the Gracieuse Maandschrift voor Jonge Dames. ${ }^{26}$

A few days later, however, Fréderique Jeanne van Asperen van der Velde-van Heel agreed to take up the position after all. It is unclear what made her change her mind. The "Good Sir" at the beginning of her letter to Sijthoff indicates that they were acquaintances at best. The opening lines explaining that she was sending him her ideas about the new magazine 'as per your agreement with v.d. Velde' suggest that he had enlisted her husband to try and talk her round. ${ }^{27}$ She was writing to Sijthoff somewhat hurriedly, admittedly without a clear understanding of his expectations, and unable to remember what was in the model prospectus that he had recently shown her. Still, she promised to come up with a preface within the next few days and on a separate page, entitled 'Contents', outlined the different sections of the magazine:

1. Literature — stories, tales, sketches, travel descriptions

2. Biography

3. Book review

4. Something for toilet or household

5. Miscellaneous

6. Fashions ${ }^{28}$

She also included a list of foreign authors that she considered suitable for translation as, by her own admission, she had not yet had the time to look at the sample magazine copies that Sijthoff had sent her. The twenty-four names offer a wide variety of female and male, established and upcoming, living and deceased authors as well as of genres and of languages: English novelists Charlotte Mary Yonge (1823-1901), George Eliot (1819-80), Dinah Mulock (1826-87), and Charlotte Brontë (1816-55; as 'Currer Bell'); best-selling American novelist Fanny Fern (1811-72), German travel writer Friedrich Gerstäcker (1816-72), and historical novelist Luise Mühlbach (1814-73); French authors Henri Murger (1822-61), Émile Souvestre (1806-54), and adventure novelist Gustave Aimard (1818-83); Swiss cartoonist Rodolphe Töpffer (1799-1846), Swedish 
writer Fredrika Bremer (1801-65), and Danish fairy-tale author Hans Christian Andersen (1805-75). Just like the Weeveringh sisters recommended particular suppliers for each type of illustration, Van Asperen van der Velde-van Heel shared her insights into the latest trends in the literary world, into what she believed readers of $D e$ Gracieuse would want to read and what genres would fit well with the format of the new magazine: 'From Miss Yonge the latest is: the young stepmother-I do not know if it has already been translated; from Murger Hélène is a darling story. G. Aimand provides good travel descriptions from America. From Andersen small tales and parables are quite usable.' Finally, she informed Sijthoff that she preferred to contribute two-and-a-half pages on a monthly basis herself, adding that the Miscellaneous section would lend itself perfectly to filling precisely this amount of space. ${ }^{29}$

At first sight, Van Asperen van der Velde-van Heel was joining forces with Sijthoff to get De Gracieuse into shape soon, hurrying to catch up and presenting her ideas without waiting for more detailed instructions. However, given her earlier refusal of the editorship, her proactive approach can also be read as a strategy for asserting her autonomy and authority. Here was an editor who did not need the publisher's prospectus to set out a vision for the new magazine, who could easily fill the literary pages without consulting any sample copies. Van Asperen van der Velde-van Heel was also setting the terms on which she was willing, and able, to edit the literary section as a time-pressed soon-to-be-mother of five. 'However, in any case, right?' she reminded Sijthoff with a veiled allusion to her advancing pregnancy, 'I will hardly be available for one thing or another in the first three, four months'. On September 20, less than two weeks before De Gracieuse was launched, she gave birth to a son. ${ }^{30}$

\section{De Gracieuse published}

From October 1862 onwards, De Gracieuse, subtitled Tijdschrift voor Jonge Dames (Magazine for Young Ladies), appeared monthly in two editions: a full edition for $f 6$ a year and a cheaper one with the fashion and needlework section only, the so-called 'Schelling edition', for $f 3,60$ a year. Single issues cost 50 or 30 cents respectively. ${ }^{31}$ In the preface to the first issue, Van Asperen van der Velde-van Heel presented the magazine's aims to make elegant fashion and tasteful home décor affordable to those on a limited budget as well as to provide edifying literature to readers regardless of social standing. ${ }^{32}$ Advertisements in the local press promised 'romantic stories after the best foreign authors', fashion plates, large needlework pattern sheets, a variety of Berlin 
wool, and crochet patterns as well as other types of content that 'may be welcome and of interest in the civilised world of women'. ${ }^{33}$ Both the double mission and the advertised contents clearly reflect the broad ideas outlined by the three editors in the planning stage. Combining these findings from the Sijthoff Archive with large-scale digital periodical research allows us to examine to what extent the published Gracieuse was built from the editors' more specific suggestions as to what foreign models to emulate, where to find the best illustrations, and what authors to include.

\section{The fashion and needlework section}

As per the Weeveringh sisters' advice, each issue contained a hand-coloured fashion plate supplied by Adolphe Goubaud. The accompanying textual material, however, is curiously trilingual, indicating that the arrangement may not have been as straightforward as they may have hoped. The magazine title is in Dutch, the information about the printer and publisher is provided in French, while the dates and captions are in English (see Figure 2). Sijthoff's correspondence archive reveals why. In a letter to Sijthoff dated May 16, 1862, Goubaud explained that De Gracieuse's expected circulation of 6,000 copies was too small to cover the production costs of the fashion plates, and proposed a compromise that involved piggybacking the new periodical on an established British women's magazine with much higher circulation figures. ${ }^{34}$ In 1860 , Goubaud had secured a contract with the London publishing couple Samuel and Isabella Beeton for the supply of monthly fashion plates to the Englishwoman's Domestic Magazine, which by 1862 had a circulation of 55,000 copies. ${ }^{35}$ The deal with Sijthoff entailed producing 6,000 additional copies of the Beetons' plates and sending them to Leiden on a monthly basis. The only difference was in the caption, which needed to be printed separately from the illustration anyway. By retaining the English text and only substituting the magazine title, the extra costs were kept to a minimum. Ironically, this meant that the plates were not as 'expressly prepared and designed for De Gracieuse' as the caption claimed. ${ }^{36}$

The arrangement not only meant that the Parisian fashion plates in De Gracieuse were all but identical to and published synchronously with those in the Englishwoman's Domestic Magazine in London. It also meant that the accompanying descriptions took the same detour. Originally published in French in Le Moniteur de la mode, they were translated into English by Isabella Beeton with considerable liberties to suit the taste and demands of British readers and to compensate for their lack of proximity to Paris. 
Her translations were in turn translated and adapted for a Dutch readership by the Weeveringh sisters. In October 1862, for instance, Beeton opened the fashion column with the observation that women looking for stylish winter outfits were spoilt for choice in the London fashion district:

The season has now arrived when ladies are beginning to think of providing themselves with winter garments, and they will certainly have but little difficulty in choosing something to their taste, for the large West-End establishments of London are now so stocked with an embarras de richesses, in the way of mantles, pardessus, cloaks, \&c., that the most fastidious would not fail to select something to please herself. ${ }^{37}$

As Margaret Beetham argues in A Magazine of Her Own? (1996), with the introduction of French fashion advice and fashion plates in 1860, the Englishwoman's Domestic Magazine imported a 'feminine ideal [...] centred on appearance and dress' that 'threatened to rewrite $[\ldots]$ a definition of femininity in terms of the domestic and the moral' ${ }^{38}$ In order to reconcile these two opposing models, the magazine offered dress patterns and instructions that enabled women to make their own fashionable clothes. Fashion and elegance were thus framed in terms of economy and practicality.

The editors of De Gracieuse provided patterns for the same reason, but theirs was perhaps the more challenging balancing exercise as Dutch normative constructions of domestic femininity were arguably even more narrowly circumscribed by values deeply embedded in Dutch society in general, such as hard work, frugality, modesty, and service to others. In the Weeveringh sisters' translation of Beeton's observations, the 'ladies' became 'housewives'. Rather than 'beginning to think of providing themselves with winter garments' right away, they prioritised the needs of their family:

The time has now come to arm oneself against winter: the housewives have stocked up the basement and pantry, seen to fuel and stove, in short arranged everything as comfortably as possible, so as to make the often dark winter days and long evenings pleasant and cheerful for their family members, old and young. Now thoughts turn to the important topic of 'clothing'. ${ }^{39}$

In a Dutch context, a simple cut-translate-and-paste approach to the fashion advice was not an option. By adding a sentence asserting the priority of domestic responsibilities on women's to-do lists, the Weeveringh sisters, in Stephan Pigeon's words, 'repurposed' 
the English original, adapting to 'national tastes and sensitivities' a passage which, unedited, may have struck Dutch readers as frivolous and self-indulgent. ${ }^{40}$

In addition to the fashion plates, De Gracieuse offered monthly pull-out pattern sheets with Dutch captions bearing the names of Emrik \& Binger as well as dozens of uncredited fashion and needlework illustrations scattered across the pages of the magazine itself. ${ }^{41}$ This seems to be exactly what the Weeveringh sisters had proposedto follow the Aglaja's model and purchase the illustrations directly from their preferred Dutch printers, who were able to supply 'more recent designs [...] than [could] be found in those plates copied one after the other'. ${ }^{42}$ Indeed, a major selling point advertised by the Aglaja was that it had become a source of reuse by Dutch, French, and German periodicals without ever having reprinted a single image itself. ${ }^{43}$

Sijthoff's correspondence archive, however, throws a different light on the matter, including a number of other options that he pursued first. As for the dress patterns, Sijthoff initially hoped to extend the deal with Gouband and Beeton. In the 16 May letter about the fashion plates, Goubaud wrote: 'I am sending you a few introductory words for good friend Beeton. You will come to an understanding with him on the yellow pattern sheets - since he has agreed to have some of his small fashions printed for you. ${ }^{44}$ Sijthoff also decided not to take up the Weeveringh sisters' suggestion to order the Berlin wool patterns from Meister. Instead he tried to enlist Silbermann of Strasbourg, who also worked for Goubaud and Beeton. Goubaud warned him that there was no way to obtain Silbermann's patterns at the same favourable rate as Beeton, and instead recommended the cheaper gouache tapestry patterns that also appeared in Cendrillon. Perhaps recalling the Weeveringh sisters' lukewarm opinion of the Cendrillon illustrations, Sijthoff ignored this advice and contacted Silbermann directly. He then enclosed Silbermann's response in a letter to Goubaud, to serve as leverage in his negotiations. Goubaud was not amused. On 30 May, he replied to Sijthoff: 'I regret, Sir, that you have taken the trouble to write to this gentleman on a matter that does not concern him in any way. ${ }^{45}$ As he went on to explain, the problem lay not so much in printing additional batches of Beeton's illustrations for De Gracieuse as in the significant costs he incurred for the design, stereotyping, and paper, which amounted to 8 to 10 centimes per sheet. The only way he could afford to charge Beeton between 5 and 12 centimes apiece was because Beeton purchased large numbers. Since orders were placed up to nine months in advance, it would be impossible for Sijthoff to have them produced to actual demand. The only alternative was to bring Beeton's 
illustrations back into production for only a fraction of his numbers, but this would be prohibitively expensive. Goubaud concluded: 'It is therefore imperative, Sir, that you give up on these illustrations - it is utterly impossible and if you had spoken to me about it when you came to see me I would have told you so immediately. ${ }^{46}$

If the negotiations yielded any result for Sijthoff, it was no doubt the realisation that the fledgling Gracieuse was too small to bear the costs of hiring different manufacturers for each step of the production process. The only viable option was unauthorized reuse: to select published illustrations from the foreign fashion press and to pass them on to Emrik \& Binger for reproduction. At this point, Sijthoff most likely left it to the Weeveringh sisters to work their scissors. Fashion and needlework illustrations in De Gracieuse were reused in two main ways, either on one-sided plates included in the magazine itself or on the large two-sided pull-out patterns sheet that came with each monthly issue. The front of these yellow sheets usually included various needlework patterns; on the back were cut-out dress patterns. Visual comparison with the magazines on the Weeveringh sisters' list of potential models indicates that the main source of the reuse was either Der Bazar or its French edition La Mode illustrée. A closer look at the captions and descriptions points to Der Bazar alone. An example is the knitted 'Dames Capuchon Pia' ('Ladies' Hood Pia') in the December 1862 issue of De Gracieuse. The month before, the same illustration was captioned 'Capote Pia' in Der Bazar and 'Capuchon Clotilde' in La Mode illustrée. ${ }^{47}$ Similarly, in August 1863, De Gracieuse opened its instructions for knitting a shawl with the remark that the garment would please many subscribers as it was both easy to make and light enough to wear on summer days. ${ }^{48}$ Der Bazar included the exact same observation; La Mode illustrée only gave the instructions, without further comment. ${ }^{49}$ It is unclear what compelled the Weeveringh sisters to source material from the German rather than the French periodical. One reason could be access to the physical copies, another language proficiency. In any case, the French fashions in De Gracieuse came from Berlin, not from Paris.

\section{The literary section}

In an undated letter to Sijthoff written during the first months of publication, J. J. Weeveringh exclaimed: 'Poor Gracieuse!' He subsequently explained that Fréderique Jeanne Van Asperen van der Velde-van Heel found the workload 'too heavy' and 'wished to step down as editor at the end of the first year'. ${ }^{50}$ Weeveringh concluded that 
this would be in the magazine's best interest, as 'agitation and overstrain' were bound to affect the quality of her work eventually. The correspondence archive contains no evidence of a resignation. On the contrary, a letter written by Van Asperen van der Velde-van Heel one year into the magazine's existence shows her firmly settled into her editorial responsibilities and routines. It shows that part of the translations for the literary section was delegated to others, with Van Asperen van der Velde-van Heel overseeing the work and keeping financial records for Sijthoff. The letter includes an overview of who had translated what in the previous six months - naming among the five translators four more women undertaking invisible work for De Gracieuse, specifying the number of lines, and listing the total payment due to each. ${ }^{51}$ In addition, Van Asperen van der Velde-van Heel was evidently also doing some of the fashion and needlework translations as well as coordinating the workflow for the periodical as a whole:

The issue of the Bazar received by post is with Emrik, who, I must say, is making good progress while moreover all is looking good in my opinion. This morning I received my own issue, so I will soon send you the translated description. [...] The ladies W. sent me their 'description of the plates', which I continued on the same draft. ${ }^{52}$

Still, some of her editorial decisions can be read in light of the heavy time constraints under which she was working. The overall layout of the literary section was more or less how she had envisioned it in her letter to Sijthoff, including serial fiction, essays on biographical, historical, and other subjects, domestic advice, miscellaneous anecdotes and proverbs, book reviews, and an overview of new sheet music. By contrast, few of the authors on her list made it into the magazine, though some, including Jean Macé, Luise Mühlbach, and Charlotte Mary Yonge, were mentioned in the new books section. Apart from a collection of proverbs 'after E. Souvestre' in the February 1863 issue, none of the signed pieces were by any of the authors that she had recommended to Sijthoff. Given her busy schedule, she may have decided that it was more time-efficient to adopt the same scissors-and-paste approach as the Weeveringh sisters and select materials from a limited set of periodicals at hand, rather than to hunt for specific authors across the magazine market.

Particularly in the early months of the magazine Van Asperen van der Velde-van Heel appears to have been relying to some extent on the foreign women's magazines on the Weevering sisters' list, including those from which they sourced content for the 
fashion and needlework section. Several items in the literary section were translated from Der Bazar, De Gracieuse's main source for the fashion and needlework illustrations, including a story about a clairvoyant, articles on cork crafting and on the history of mirrors, a two-part piece on Shakespeare, and a letter by Anna Boleyn. ${ }^{53}$ For the greater part of 1862-63, the section was dominated by translations of Constance Chorley, a sensational serial tale running anonymously from October 1861 to May 1863 in the Englishwoman's Domestic Magazine, which shared its fashion plates with De Gracieuse. The Englishwoman's Domestic Magazine was also the source of translated essays on colour and on precious stones, while many of the monthly recipes and other household tips were taken from Isabella Beeton's popular Book of Household Management (1859-61). ${ }^{54}$

Like the fashion advice, the reuse in the literary section was not always a 'straightforward task of reading, cutting, and pasting an old text to make it "new" again'. ${ }^{55}$ Constance Chorley, for example, closely followed the original for the first six instalments only, relating the ordeals of a young woman and her little brother who fled their home after nearly dying in a fire set by their father to collect insurance money for his ailing bookselling business. In the Englishwoman's Domestic Magazine, the story ran on for several more months before coming to a dramatic conclusion. The Dutch translation apparently failed to catch on with the readers of De Gracieuse. According to H. M. C. van Oosterzee, who later identified himself as the translator, it was Sijthoff who asked for the serial to be brought to a close. ${ }^{56}$ After a final attempt to increase reader engagement by replacing English names such as Peter, Madgie, and Jemmy with familiar Dutch ones like Piet, Leentje, and Jaap, the series ended abruptly with a quick succession of plot twists happily culminating in marriage.

In another example of how 'old' texts were 'made new', Van Asperen van der Velde-van Heel sourced a significant amount of material from foreign illustrated weeklies. These texts usually focused on more general historical or scientific topics, which commonly appeared in British, French, and German periodicals for women in the 1860s but were still unusual in Dutch women's magazines. The practice of 'copy-andpaste' journalism across language boundaries thus enabled Van Asperen van der Veldevan Heel to assemble a magazine covering a wider variety of topics and to adopt a more international outlook than immediate predecessors and contemporaries like Pénélope, Aglaja, Maandschrift voor dames, and Maria en Martha (1844-56). ${ }^{57}$ Between October 1862 and March 1863, the period covering the first volume of De Gracieuse, at least 
eight items were most likely translated from recent issues of the French Le Magasin pittoresque (1833-1938), including an article about primary education in Denmark, an article about wigs, a tale about a magpie, and a piece about the screech owl. ${ }^{58} D e$ Gracieuse also published an essay on sponge-fishing in Syria that first appeared in the Illustrated London News (1842-1989) and a story set in the Alps by the Austrian writer Adolph Pichler that was first published in the popular German illustrated family weekly Die Gartenlaube (1853-1944). ${ }^{59}$

Similarly, Van Asperen van der Velde-van Heel selected from foreign-language sources several biographical essays featuring female historical figures from different countries, such as Isabella I of Castile (1451-1504) and Queen Elizabeth I (1533-1603), Italian poet Vittoria Colonna (1492-1547), German entrepreneur Barbara Uthmann (c.1514-75), Swiss-born painter Angelica Kauffman (1741-1807), and Spanish opera singer Maria Malibran (1808-36) ${ }^{60}$ Most of these were in all likelihood translated directly from Ida von Düringsfeld's recently published collection of women's biographies Das Buch denkwürdiger Frauen (1862). The story 'Doctor Clarke', translated from Der Bazar, featured a fictional character loosely based on Elizabeth Blackwell (1821-1910), the first woman to obtain a medical degree in the United States. ${ }^{61}$ As Lotte Jensen has pointed out, professional women like Doctor Clarke were not presented as role models to the readers of De Gracieuse. ${ }^{62}$ The story's opening paragraph offers a scathing critique of the "so-called "emancipation of women" [...] which actually amounts to a ridiculous mimicking of the life of men'. ${ }^{63}$

Indeed, we know full well that the woman who oversteps the boundaries of womanhood throws away her highest dignity, tramples on her most beautiful jewel; we are deeply convinced that woman can only be happy, and make happy, as woman. Nor do we ask for woman [sic.] to be admitted to all functions and activities that are in the possession of the stronger half of mankind. Neither the disposition of her body nor the faculties of her mind give rise to this, and we would like to see woman placed neither in the pulpit nor in the judicial seat, just as we hold a woman's hand to be ill-suited to make the blacksmith's heavy hammer resound on the anvil. What we wish for is this, that those fields of activity are opened to woman which have been assigned to her by nature and to which she can safely be said to have a certain calling. And this first and foremost includes medicine. ${ }^{64}$ 
Whether out of choice or necessity, the women behind De Gracieuse may not have held the same views, their paid work as editors and translators testifying to the active lives they led outside the narrowly defined boundaries of femininity. Still, the reality of the market was that the magazine's best chance at survival was to target a wide mainstream readership, which in Jensen's words 'was not ready for such an extension of the female domain'. ${ }^{65}$ The 'New Books' section explicitly reflected on this in January 1863, in a brief review of Florence Nightingale's Notes on Nursing (1862), which had just come out in a Dutch translation by Anne Busken Huet-van der Tholl, published by J. J. Weeveringh. The reviewer doubted that the 'English heroine of the Crimea' would have attracted any followers in a Dutch context, as 'Dutch women and girls are not so eccentric and prefer to find work in their own home or city, or at least in a narrower sphere than Miss N.' ${ }^{66}$ By adopting a more international approach than any of its predecessors and competitors, De Gracieuse inevitably found itself in a field of tension between the international developments on women's participation in the labour market and the more conservative views of its Dutch readership.

\section{De Gracieuse transformed}

Throughout 1862-64, De Gracieuse struggled to stay afloat. With 1,000 subscribers to the Schelling edition and just 350 to the full edition, the magazine scrambled to secure a sizable readership. In an attempt to strengthen its position in the market, Sijthoff bought the publishing rights to two competing titles, the needlework magazine Victoria (1862) and the women's magazine Maandschrift voor dames, which had around 1,000 subscribers at the time ${ }^{67}$ Both periodicals subsequently ceased publication. At an auction in October 1864, he also acquired the rights to the Aglaja for 2,639 guilders. ${ }^{6}$ The new subtitle, Geïllustreerde Aglaja (Illustrated Aglaja), under which De Gracieuse appeared from December onwards seemed to indicate that De Gracieuse had annexed its oldest and most formidable rival, with over 5,000 subscribers in its heydays. ${ }^{69}$ Advertisements in the local press even suggested a triad. The Opregte Haarlemsche Courant announced in bold capitals: 'The Gracieuse, the Aglaja, and the German Bazar united. ${ }^{70}$ That is not what had happened. In reality, the new title marked the end, in all but name, of not one but two periodicals, as the Aglaja disappeared altogether and De Gracieuse was transformed into an edition of Der Bazar. 
A few months earlier, Sijthoff had received a letter from Berlin. In faulty Dutch with an unmistakable German twist, a man identifying himself as Louis Schäfer, the publisher of Der Bazar, had accused Sijthoff of unauthorized reprinting:

Through a good friend I came into possession of a large number of issues of your magazine 'Gracieuse' and saw to my greatest surprise that not only illustrations, patterns with descriptions but also a large number of articles were copied from my 'Bazar', so that your entire magazine is nothing but a complete copy. ${ }^{71}$

Fearing the unauthorized reuse would thwart a recent offer from Amsterdam to buy the clichés, Schäfer gave Sijthoff a choice: either pay a good price for the illustrations or face legal action as well as direct competition from an official Dutch edition of Der Bazar, which Schäfer was planning to establish soon, regardless of Sijthoff's decision. Sijthoff's correspondence archive shows that the threats proved effective. In the following weeks, letters went back and forth between Leiden and Berlin until the two publishers reached an agreement. ${ }^{72}$ Sijthoff adjusted the publication schedule of $D e$ Gracieuse from monthly to twice a month to match Der Bazar's fortnightly fashion and needlework issues. For a fixed annual sum, he purchased 4,000 copies of the preprinted sheets of Der Bazar with the illustrations only, the front page topped by the lavish Bazar-style masthead that Schäfer had designed specifically for De Gracieuse. Copies of each new German issue were sent to Sijthoff in Leiden, to the editors, and to the printers Emrik \& Binger in Haarlem as soon as they came off the presses, so the preprinted sheets could be completed with Dutch translations of the original German text.

From 15 December 1864 onwards, De Gracieuse appeared as the official Dutch edition of Der Bazar, its circulation rising from 10,000 copies in 1871 to 15,000 in 1893 and 22,000 in 1904. ${ }^{73}$ It remained a staple in the Dutch magazine market until its demise in 1936. Susanna Maria and Johanna Weeveringh stayed on as editors, possibly until their deaths in 1882 and 1887 respectively. Fréderique Jeanne van Asperen van der Velde-van Heel gave up her post sooner, though when exactly is unclear. She was replaced by a Miss M. van Gogh, who according to Sijthoff's biographer was succeeded in 1887 by a Miss Doorman from Utrecht, in all likelihood the author and translator Christine Doorman (1858-1941). ${ }^{74}$ Sijthoff's correspondence archive contains no letters documenting how the contract with Der Bazar affected the nature of their work and the division of labour among the three editors, but the impact must have been significant. 
The innovative 'scissors-and-paste' approach of the first two years came to an abrupt end as the magazine became part of a long-standing international brand. The broad thematic scope of De Gracieuse was narrowed to fashion and needlework only, and since all visual and textual contents came directly from Der Bazar, there was no more need for creative gatekeeping. The editors' job was most likely reduced to that of translator or coordinator of the translations.

For all De Gracieuse's subsequent popularity and longevity, the brief period of two years before the affiliation constitutes a valuable case study in its own right. As this article has shown, Sijthoff's dealings with high-profile fashion publishers such as Goubaud and Schäfer tell only half the story of De Gracieuse. Behind the scenes, three female editors poured their fashion expertise, language skills, knowledge of the literary market, and commercial acumen into developing a new periodical for women. While only Sijthoff's name appeared on the cover of De Gracieuse, they were the ones wielding the scissors, turning the common nineteenth-century practice of 'scissors-andpaste' journalism into a creative and innovative process. When read alongside the evidence from the Sijthoff Archive and the various foreign periodicals from which material was taken, the early Gracieuse provides a unique insight into the creative processes driving the making of a nineteenth-century women's magazine.

Figure 1. The Weeveringh sisters' list of periodicals in J. J. Weeveringh's 2 April 1862 letter to A. W. Sijthoff, with annotations by an unknown hand. Leiden University Libraries. Figure reproduced under the Creative Commons CC-BY License. http://hdl.handle.net/1887.1/item:1654020.

Figure 2. Example of a fashion plate in De Gracieuse, with the captions in English. May 1863. Gemeentemuseum Den Haag. Image in the public domain. https://resolver.kb.nl/resolve?urn=urn:gvn:GMDH01:200000002.

\footnotetext{
${ }^{1}$ Die Modenwelt had editions in London, Paris, The Hague, Brussels, Milan, Madrid, Porto, Malmö, Copenhagen, Prague, Budapest, Warsaw, Saint Petersburg, Buenos Aires, and New York. For a full overview, see Ana Cláudia Suriani da Silva, 'From Germany to Brazil: The History of the Fashion Magazine A Estação, an International Enterprise', in Books Without
} 
Borders. Volume 1. The Cross-National Dimension in Print Culture, ed. Robert Fraser and Mary Hammond (Houndmills: Palgrave Macmillan, 2008), 74-6. Le Moniteur de la mode was read 'from Saint Petersburg to Rio de Janeiro', appearing in French, German, English, Russian, Italian, Spanish, and Portuguese. See Raymond Gaudriault, La Gravure de mode féminine en France (Paris: Éditions de 1'Amateur, 1983), 121. Der Bazar in the early 1870s boasted a circulation of over half a million copies in German, English, French, Spanish, Dutch, Russian, Italian, Hungarian, and Czech. For a more detailed history of the early years of Der Bazar, see Marianne Van Remoortel, 'Women Editors and the Rise of the Illustrated Fashion Press in the Nineteenth Century', Nineteenth-Century Contexts 39, no. 4 (2017): 269-95.

${ }^{2}$ The Dictionary of Nineteenth-Century Journalism defines scissors-and-paste journalism as a 'term, often used pejoratively' in the nineteenth century 'for the wide-spread practice of excerpting from or recycling of articles from other publications'.

${ }^{3}$ Stephan Pigeon, 'Steal it, Change it, Print it: Transatlantic Scissors-and-Paste Journalism in the Ladies' Treasury, 1857-1895', Journal of Victorian Culture 22, no. 1 (2017): 26.

${ }^{4}$ See, for instance, M. H. Beals's Scissors and Paste Database of reuse in nineteenth-century British newspapers (http://scissorsandpaste.net/); Bob Nicholson, "“You Kick the Bucket; We Do the Rest!": Jokes and the Culture of Reprinting in the Transatlantic Press', Journal of Victorian Culture 17, no. 3 (2012): 273-86; David A. Smith, Ryan Cordell, and Elizabeth Maddock Dillon, 'Infectious Texts: Modeling Text Reuse in Nineteenth-Century Newspapers', Proceedings of the Workshop on Big Humanities (IEEE Computer Society Press, 2013), http://www.ccs.neu.edu/home/dasmith/infect-bighum-2013.pdf; Priti Joshi, 'Scissors-and-Paste: Ephemerality and Memorialization in the Archive of Indian Newspapers', Amodern 7 (2017), https://amodern.net/article/scissors-and-paste/.

${ }^{5}$ For scissors-and-paste journalism as gatekeeping, see M. H. Beals, 'The Role of the Sydney Gazette in the Creation of Australia in the Scottish Public Sphere', in Historical Networks in the Book Trade, ed. Catherine Feely and John Hinks (Abingdon: Routledge, 2017), 148-70. For scissors-and-paste journalism as an editorial practice, see Will Slauter, Who Owns the News? A History of Copyright (Stanford: Stanford University Press, 2019), particularly chapter 3

'Scissors Editors: Cutting and Pasting in Early America'.

${ }^{6}$ Pigeon, 'Steal it, Change it, Print it', 26.

${ }^{7}$ Ibid., 25.

${ }^{8}$ See Melvin Wevers and Thomas Smits, 'The Visual Digital Turn: Using Neural Networks to Study Historical Images', Digital Scholarship in the Humanities (2019), https://doi.org/10.1093/llc/fqy085; Paul Fyfe and Qian Ge, 'Image Analytics and the Nineteenth-Century Illustrated Newspaper', Journal of Cultural Analytics (2018), https://doi.org/10.22148/16.026. 
${ }^{9}$ Susanna Maria Weeveringh is listed as an embroiderer in the Haarlem Population Register for 1849-59, https://www.wiewaswie.nl/nl/detail/85978019; Advertisement, Opregte Haarlemsche Courant, June 8, 1853, 3. All Dutch newspapers cited were accessed online at https://www.delpher.nl.

${ }^{10}$ According to Kruseman's biographer J. W. Enschedé, the editorship was shared by Abraham van Lee (an Amsterdam journalist whose work Kruseman published) and family, with responsibility for testing the needlework patterns resting with the Weeveringh sisters. See J. W. Enschedé, A. C. Kruseman, vol. 1 (Amsterdam: Van Kampen, 1898), 118.

${ }^{11}$ Enschedé, Kruseman, 50.

${ }^{12}$ Lotte Jensen, 'De Nederlandse vrouwenpers in een internationaal perspectief', Nederlandse Letterkunde 6, no. 3 (2001): 229.

${ }^{13}$ Ibid.

${ }^{14}$ Letter from J. J. Weeveringh to A. W. Sijthoff, April 2, 1862, SYT A 1862, no. 59, Leiden University Library, Leiden. All translations in this article are mine.

${ }^{15}$ Ibid.

${ }^{16}$ Ibid.

${ }^{17}$ Ibid.

${ }^{18}$ Ibid. According to the relative value calculator on the website of the Dutch International Institute of Social History (IISH; http://www.iisg.nl/hpw/calculate.php), 20 guilders is about $€ 200$ in today's money.

${ }^{19}$ Enschedé, Kruseman, 578.

${ }^{20}$ Letter from J. J. Weeveringh to A. W. Sijthoff, July 15, 1862, SYT A 1862, no. 60, Leiden University Library, Leiden.

${ }^{21}$ The birth records, accessible via the Dutch genealogical database WieWasWie (https://www.wiewaswie.nl/), list births in 1856, 1857, 1858, 1861, and 1862. Three more children were born in 1864, 1865, and 1869. While her husband is described as a bookseller, Van Asperen van der Velde-van Heel is consistently listed as without occupation in all of these records.

${ }^{22}$ Letter from J. J. Weeveringh to A. W. Sijthoff, July 15, 1862, SYT A 1862, no. 60, Leiden University Library, Leiden.

${ }^{23}$ Ibid.

${ }^{24}$ Ibid.

${ }^{25}$ Sarah Thorp's birth, marriage, and death records are accessible at https://www.wiewaswie.nl/.

${ }^{26}$ Letter from J. J. Weeveringh to A. W. Sijthoff, July 15, 1862, SYT A 1862, no. 60, Leiden University Library, Leiden.

${ }^{27}$ Letter from Fréderique Jeanne van Asperen van der Velde-van Heel to A. W. Sijthoff, July 19, 1862, SYT A 1862, no. 6, Leiden University Library, Leiden. 
${ }^{28}$ Ibid.

${ }^{29}$ Ibid.

${ }^{30}$ Birth certificate of Jacobus Cornelis van Asperen van der Velde, accessible via

https://www.wiewaswie.nl/nl/detail/33676731.

31 'Jongst verschenen boeken', Nieuwsblad voor den boekhandel, 9 October 1862, 1.

32 'Voorwoord', De Gracieuse, October 1862, 1.

${ }^{33}$ See, for instance, 'Gracieuse, Tijdschrift voor Dames', Opregte Haarlemsche Courant, February 17, 1863, 6 .

${ }^{34}$ Letter from Adolphe Goubaud to A. W. Sijthoff, May 16, 1862, SYT A 1862, no. 38, Leiden University Library, Leiden.

3555,000 is the number provided by Goubaud in his 16 May letter. For a discussion of the Beetons' deal with Goubaud, see Marianne Van Remoortel, 'Women Editors' Transnational Networks in the Englishwoman's Domestic Magazine and Myra's Journal', in Women, Periodicals and Print Culture in Britain, 1830s-1900s: The Victorian Period, ed. Alexis Easley, Clare Gill, and Beth Rodgers (Edinburgh: Edinburgh University Press, 2019), 46-56. ${ }^{36}$ Fashion plate, De Gracieuse, October 1862, n.p. The caption appeared on all monthly fashion plates before the affiliation with Der Bazar.

37 'The Fashions', Englishwoman's Domestic Magazine, October 1862, 284.

${ }^{38}$ Margaret Beetham, A Magazine of Her Own? Domesticity and Desire in the Woman's Magazine, 1800-1914 (London: Routledge, 1996), 74, 76.

39 'Modes', De Gracieuse, November 1862, 27. The rest of the paragraph is a fairly straightforward translation of Beeton's text. The 'large West-End establishments of London' are stripped of their geographical specificity and translated as 'warehouses and shops everywhere'. ${ }^{40}$ Pigeon, 'Steal it, Change it, Print it', 25, 27.

${ }^{41}$ The digitised version of De Gracieuse in the Memory of the Netherlands database (https://www.geheugenvannederland.nl) does not include the pattern sheets. To examine these sheets, I consulted the copies of De Gracieuse in the Allard Pierson Special Collections of the University of Amsterdam (UBM: Z 1706).

${ }^{42}$ Letter from J. J. Weeveringh to A. W. Sijthoff, April 2, 1862.

43 'Berigt', Aglaja, June 1854, 4.

${ }^{44}$ Letter from Adolphe Goubaud to A. W. Sijthoff, May 16, 1862, SYT A 1862, no. 38, Leiden University Library, Leiden.

${ }^{45}$ Letter from Adolphe Goubaud to A. W. Sijthoff, May 30, 1862, SYT A 1862, no. 39, Leiden University Library, Leiden.

${ }^{46}$ Ibid.

47 'Dames Capuchon Pia', De Gracieuse, December 1862, 33; 'Capote Pia', Der Bazar, November 15, 1862, 329; 'Capuchon Clotilde', La Mode illustrée, November 17, 1862, 369. 
48 'Wollen doek', De Gracieuse, August 1863, 63.

49 'Wollenes gestricktes Tuch (Shawl)', Der Bazar, July 15, 1863, 207; 'Châle tricoté en laine', La Mode illustrée, July 13, 1863, 218.

${ }^{50}$ Letter from J. J. Weeveringh to A. W. Sijthoff, undated, SYT A 1862, no. 58, Leiden University Library, Leiden.

${ }^{51}$ Letter from Fréderique Jeanne van Asperen van der Velde-van Heel to A. W. Sijthoff, October 1, 1863, SYT A 1863, no. 70, Leiden University Library, Leiden. The four women are identified as Miss Jorissen, Ernestine van B., Miss H. A. Krooneman, and Miss Van de Waarden. The fifth name is that of a relatively well-known male translator, H. M. C. van Oosterzee (1806-77).

${ }^{52}$ Letter from Fréderique Jeanne van Asperen van der Velde-van Heel to A. W. Sijthoff, October 1, 1863, SYT A 1862, no. 70, Leiden University Library, Leiden.

${ }^{53}$ See 'Die Hellseherin' (Der Bazar, October 23, 1862) and 'De clairvoyante' (De Gracieuse, December 1862); 'Kork-Application' (Der Bazar, June 8, 1862) and 'Het gebruik van kurk als dameshandwerk' (De Gracieuse, November 1862); 'Zur Geschichte der Spiegel' (Der Bazar, July 8, 1864) and 'Over het gebruik van spiegels' (De Gracieuse, September 1864); 'William Shakespeare' (Der Bazar, May 23 and June 8, 1864) and 'Herinnering aan Shakespeare' (De Gracieuse, June-July 1864); 'Ein Brief von Anna Boleyn' (Der Bazar, April 8, 1864) and 'Een brief van Anna Boleyn' (De Gracieuse, September 1864).

${ }^{54}$ See 'Colour, in Dress, Furniture, and Gardening' (Englishwoman's Domestic Magazine, June 1862 ) and 'Iets over de kleuren in kleeding, opschik, bloemen, enz.' (De Gracieuse, October 1862); 'Concerning Precious Stones' (Englishwoman's Domestic Magazine, March-April 1863) and 'Over edelgesteenten' (De Gracieuse, June-July 1863).

${ }^{55}$ Pigeon, 'Steal it, Change it, Print it', 26.

${ }^{56}$ H. W. T. Tydeman. 'Levensschets van H. M. C. van Oosterzee', in Jaarboek van de Maatschappij der Nederlandse Letterkunde (Leiden: Maatschappij der Nederlandsche Letterkunde, 1878), 89. The identification is at odds with information provided by Sijthoff's correspondence archive. Fréderique Jeanne van Asperen van der Velde-van Heel identifies a Miss Jorissen as the translator of the final instalments. (SYT A 1863, no. 70, Leiden University Library, Leiden.)

${ }^{57}$ For an overview of nineteenth-century Dutch women's magazines see Lotte Jensen, 'Bij uitsluiting voor de vrouwelijke sekse geschikt'. Vrouwentijdschriften en journalistes in Nederland in de achttiende en negentiende eeuw (Hilversum: Verloren, 2001). ${ }^{58}$ See 'Les six repas et l'instruction primaire en Danemark' (Le Magasin pittoresque, May 1862 ) and 'De zes maaltijden en het lager onderwijs in Denemarken' (De Gracieuse, December 1862); 'Les perruques' (Le Magasin pittoresque, May 1862) and 'Pruiken en pruikmakers' (De Gracieuse, December 1862); 'Histoire d'une pie' (Le Magasin pittoresque, May 1862) and 
'Geschiedenis van een ekster' (De Gracieuse, December 1862); 'Chouette blessée' (Le Magasin pittoresque, June 1862) and 'De katuil' (De Gracieuse, January 1863).

${ }^{59}$ See 'Sponge-fishing in Syria' (Illustrated London News, August 22, 1862) and

'Sponsvisscherij in Syrië' (De Gracieuse, February 1863); 'Aus den Tyroler Bergen' (Die

Gartenlaube, 1863) and 'Uit de bergen van Tyrol' (De Gracieuse, February 1864).

${ }^{60}$ See 'Isabella van Spanje en Elisabeth van Engeland. Eene geschiedkundige parallel' (De

Gracieuse, November 1862) and the chapter 'Isabella von Spanien und Elisabeth von England.

Eine historische Parallele' in Karl Joseph von Hefele's Der Cardinal Ximenes und die

Kirchlichen zustände Spaniens am Ende des 15. und Anfange des 16. Jahrhunderts (1851). For

'Barbara Uttmann. 1547' (De Gracieuse, March 1863), 'Maria Malibran' (De Gracieuse, March 1864), 'Angelika Kaufmann' (De Gracieuse, June 1864), and Vittoria Colonna (De Gracieuse, September 1864) see Ida von Düringsfeld's Das Buch denkwürdiger Frauen (1863).

${ }^{61}$ See 'Doctor Clarke' (De Gracieuse, October 1862) and 'Doctor Clarke' (Der Bazar, October $1,1861)$.

${ }^{62}$ Jensen, 'Bij uitsluiting voor de vrouwelijke sekse geschikt', 178-79.

63 'Doctor Clarke', De Gracieuse, October 1862, 41.

${ }^{64}$ Ibid.

${ }^{65}$ Jensen, 'Bij uitsluiting voor de vrouwelijke sekse geschikt', 179.

66 'Nieuwe boeken,' De Gracieuse, January 1863, 183.

${ }^{67}$ R. van der Meulen, Een veertigjarige uitgeversloopbaan. A. W. Sijthoff te Leiden

(Amsterdam: Van Kampen, 1891), 61.

68 'Binnenland', Dagblad van Zuid-Holland en 's Gravenhage, October 29, 1864, 3.

${ }^{69}$ Jensen cites a circulation of 5,500 copies in 1854. See Jensen, 'Bij uitsluiting voor de vrouwelijke sekse geschikt', 130.

70 'De Gracieuse', Opregte Haarlemsche Courant, December 8, 1864, 4.

${ }^{71}$ Letter from Louis Schäfer to A. W. Sijthoff, September 20, 1862, SYT A 1862, no. 158,

Leiden University Library, Leiden. Because many of the errors in the letter are due to the close linguistic proximity of Dutch and German, I chose not to translate them into English.

${ }^{72}$ Letters from Louis Schäfer to A. W. Sijthoff, October 5, November 4, 7, 26, and December

12, 24, SYT A 1862, nos. 159-65, Leiden University Library, Leiden.

${ }^{73}$ Van der Meulen, Een veertigjarige uitgeversloopbaan, 62; Christine Delhaye, Door consumptie tot individu: Modebladen in Nederland, 1880-1914 (Amsterdam: Aksant, 2008), 13.

${ }^{74}$ Van der Meulen, Een veertigjarige uitgeversloopbaan, 67. 